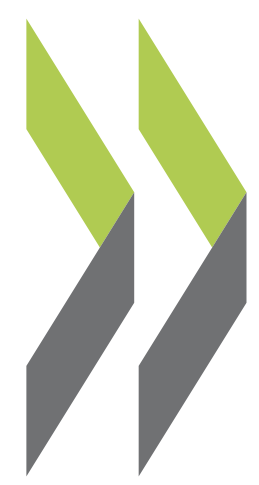

OECD Economics Department Working Papers No. 448

Slovakia's Introduction of a Flat Tax as Part of Wider Economic Reforms

\section{Anne-Marie Brook, WAlli Leibfritz}


Organisation de Coopération et de Développement Economiques

Organisation for Economic Co-operation and Development

03-Oct-2005

ECONOMICS DEPARTMENT

English - Or. English

SLOVAKIA'S INTRODUCTION OF A FLAT TAX AS PART OF WIDER ECONOMIC REFORMS

ECONOMICS DEPARTMENT WORKING PAPERS No. 448

by Anne-Marie Brook and Willi Leibfritz

All Economics Department Working Papers are now available through OECD's Internet Web at http://www.oecd.org/eco 


\section{TABLE OF CONTENTS}

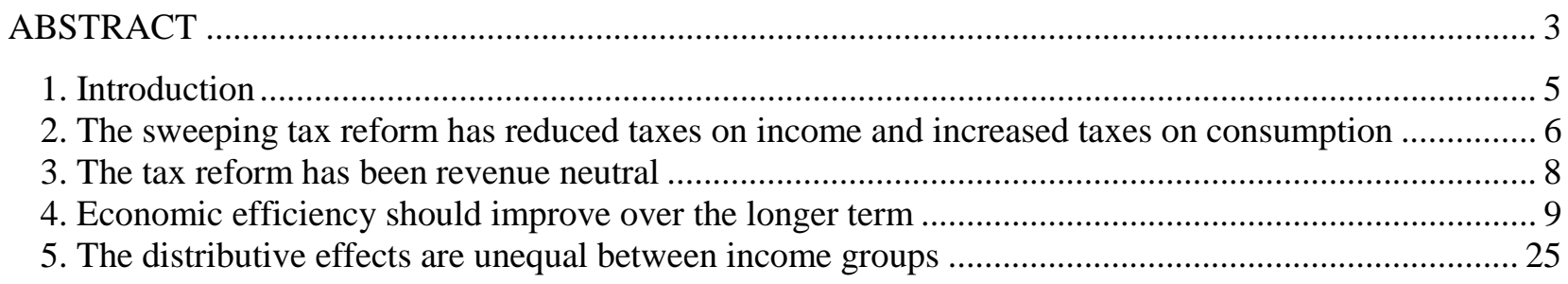

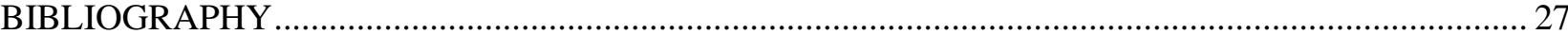

\section{Tables}

Table 1. Flat taxes on personal income: an international comparison................................................. 8

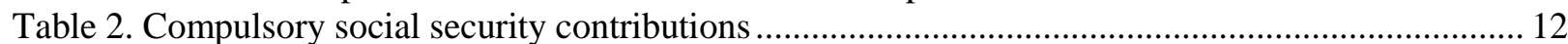

Table 3. Effective Average Tax Rates (EATR) at Corporate Level....................................................... 22

Table 4. Effective Marginal Tax Rates (EMTR) at Corporate Level ....................................................... 22

\section{Figures}

Figure 1. Effective marginal income tax rates: single tax payer …..................................................... 6

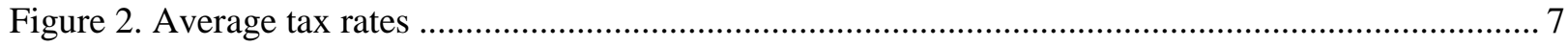

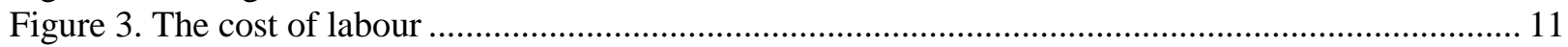

Figure 4. Tax wedges on low-wage labour, international comparison................................................. 12

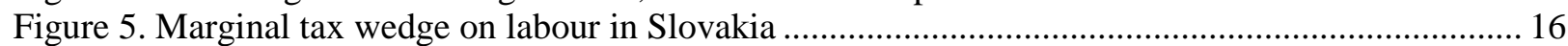

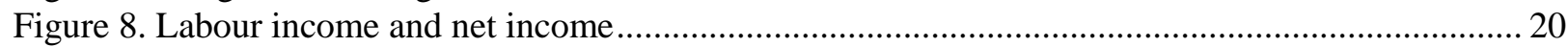

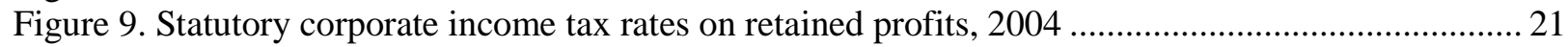

Figure 10. Effective average tax burden of companies in Europe ..................................................... 22

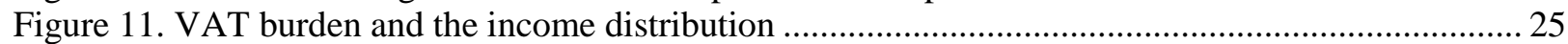

\section{Boxes}

Box 1. The case for cutting payroll taxes for low skilled workers......................................................... 14 Box 2. Assessing distortions of capital taxation between different sources of investment financing: some

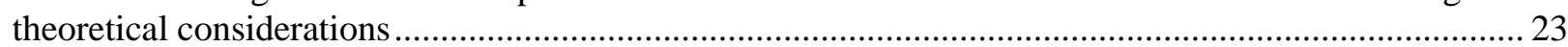




\section{ABSTRACT \\ Slovakia's introduction of a flat tax as part of wider economic reforms}

Slovakia's fundamental tax reform of 2004 considerably improved the simplicity and efficiency of the tax system by eliminating exemptions and special regimes and setting the rates for the personal income tax (PIT), the corporate income tax (CIT) and the value added tax (VAT) all equal to 19\%. This paper assesses the impact of this reform in the context of Slovakia's wider package of economic reforms. With respect to economic efficiency, the two key conclusions are as follows: First, the reforms are expected to improve both the level and efficiency of capital investment in Slovakia - although further improvements could be made by eliminating the double taxation on projects financed by retained profits. Second, the combination of the tax and social benefit reforms has enhanced the incentives for unemployed workers to seek work, which should result in higher labour supply. Labour demand should also have increased, thanks to the more flexible labour market. However, as overall taxes on labour remain high, labour demand for very low skilled workers may not pick up without further reforms to reduce the cost of employing such workers. With respect to equity considerations the assessment is less clear cut. On the one hand the flat personal income tax has benefited both low income earners and very high earners, particularly those with families, while middle-income earners, particularly single earners appear to be somewhat worse off. The increase in VAT and the welfare reform also have distributive effects. The net result of these reforms has been a significant cut in the real incomes of social beneficiaries who are not working. On the other hand, by raising labour productivity and reducing structural unemployment the reforms have the potential to benefit the low-skilled population also - provided other public policies are in place to facilitate this outcome.

This Working Paper relates to the 2005 OECD Economic Survey of the Slovak Republic (www.oecd.org/eco/surveys/slovakia)

JEL classification: E62, H21, H53, J3

Keywords: Tax policy; Flat tax; Social Security; Labour Taxation; Capital Taxation.

\section{RÉSUMÉ}

\section{L’impôt à taux unique dans le contexte de réformes économiques Slovaques}

La réforme fiscale radicale mise en place par la Slovaquie en 2004 a fortement accru la simplicité et l'efficience du système fiscal en supprimant les exemptions et les régimes spéciaux et en fixant un taux uniforme de $19 \%$ pour l'impôt sur le revenu des personnes physiques (IRPP), l'impôt sur le revenu des sociétés (IRS) et la taxe sur la valeur ajoutée (TVA). Ce document évalue l'incidence de cette réforme dans le contexte d'une série plus générale de réformes économiques mises en œuvre par la Slovaquie. Du point de vue de l'efficience économique, les deux principales conclusions sont les suivantes : En premier lieu, les réformes vont sans doute augmenter à la fois le niveau et l'efficience de l'investissement en Slovaquie - même si une amélioration reste possible en supprimant la double imposition des investissements financés par les bénéfices non distribués. En second lieu, la réforme fiscale, conjuguée à une réforme du système de prestations sociales, renforce les incitations pour les chômeurs à chercher du travail, ce qui devrait accroître l'offre de main-d'œuvre. La demande de main-d'œuvre doit aussi avoir augmenté, grâce à la plus grande flexibilité du marché du travail. Cependant, l'imposition totale du travail demeurant élevée, la demande pour les travailleurs très peu qualifiés n'augmentera peut-être pas en l'absence de mesures supplémentaires pour réduire le coût de l'embauche de ces travailleurs. En ce qui concerne les considérations relatives à l'équité, l'évaluation est moins tranchée. D'un côté, le taux uniforme de l'impôt sur le revenu des personnes physiques profite à la fois aux catégories à bas revenus et 
à aux titulaires de revenus très élevés, en particulier ceux qui ont une famille, tandis que les catégories à revenu moyen, en particulier les célibataires, semblent quelque peu défavorisées. L'alourdissement de la TVA et la réforme de la protection sociale ont aussi des effets redistributifs. Au total, ces réformes se traduisent par une diminution sensible des ressources des bénéficiaires de prestations sociales qui ne travaillent pas. D'un autre côté, en rehaussant la productivité du travail et en réduisant le chômage structurel, les réformes vont sans doute bénéficier aussi à la population peu qualifiée - à condition que des mesures complémentaires soient mises en place pour faciliter ce résultat.

Ce Document de travail se rapporte à l'Étude économique de l'OCDE de la République slovaque, 2005 (www.oecd.org/eco/etudes/slovaquie).

Classification JEL : E62, H21, H53, J3

Mots-clés : politique fiscale ; impôt uniforme ; sécurité sociale ; fiscalité du travail ; fiscalité du capital.

\section{Copyright OECD 2005}

Application for permission to reproduce or translate all, or part of, this material should be made to: Head of Publications Service, OECD, 2 rue André-Pascal, 75775 Paris Cedex 16, France. 
ECO/WKP(2005)35

\title{
SLOVAKIA'S INTRODUCTION OF A FLAT TAX AS PART OF WIDER ECONOMIC REFORMS
}

\author{
Anne-Marie Brook and Willi Leibfritz ${ }^{l}$
}

\section{Introduction}

1. In 2004 the government implemented a fundamental tax reform which unified the rate structure of the tax system by setting the tax rates of the personal income tax (PIT), the corporate income tax (CIT) and the value added tax (VAT) all equal to 19\%. Together with these changes in tax rates many exceptions, exemptions and special regimes were eliminated. This reform has made the tax system much simpler and more transparent and it is widely judged that its effect on the economy will be positive.

2. This paper describes the main elements of this reform and, together with the impact of labour market and welfare reform, examines its impact on effective tax rates of workers and investors. It also looks at how different income groups are affected.

3. With respect to the impact on investment, it is clear that tax rates on capital returns have been reduced significantly and that a more even playing-field has been created with respect to different types of investment finance. This can be expected to improve both the level and efficiency of capital investment in Slovakia. However, the tax rules are disadvantageous for projects financed by retained profits, which may adversely affect very small firms that have limited or no access to equity and debt markets. This problem could be rectified by changes to the capital gains tax regime.

4. With respect to the labour market, it is shown that the majority of workers have experienced drops in both their marginal and average tax rates, leading to higher net incomes, although there are some offsetting effects from higher consumption taxes. On the other hand, the cuts in social assistance benefits have reduced net incomes for the long-term unemployed and some very low-income workers. Cuts in net replacement rates for the unemployed were, to some extent, an inevitable side-effect of successfully enhancing the incentives for unemployed workers to seek work, in order to significantly increase the labour supply. Nonetheless, other policies may be necessary to combat the adverse effects of increased poverty rates. Labour demand should also increase, thanks to a new labour code that has improved the flexibility of the labour market. However, most unemployed workers are relatively low-skilled and it is not clear that labour demand for this segment of workers will pick up without further reforms to reduce the cost of employing such low-skilled workers. In particular, this paper recommends significant cuts to employers' social security contributions for very low-wage workers.

1. This paper is based largely on material from the OECD Economic Survey of the Slovak Republic published in September 2005 under the authority of the Economic and Development Review Committee (EDRC). The authors would like to thank Rauf Gönenç, Andrew Dean, Val Koromzay, Chris Heady for valuable comments on earlier drafts, as well as Herwig Immervol and David Barber in the OECD Directorate for Employment, Labour and Social Affairs and Ana Cabreiro-Gomez in the OECD Centre for Tax Policy and Administration for their production and analysis of much of the data. Special thanks go to Roselyne Jamin for technical assistance and to Nadine Dufour and Lillie Kee for technical preparation. 
5. Overall, in comparison with the previous system, the recent reforms have significantly simplified the tax system and improved incentives for both capital investment and labour supply. Thus, in terms of economic growth it can be expected that the effects of the reforms on the economy are positive. At the same time, however, the reforms have reduced the extent of income redistribution, leaving unemployed people, and some of those with very low incomes, worse off. The introduction of a flat income tax rate (above the basic exemption) means giving up the notion - based on the fact that the marginal utility for money is lower at higher income levels - that a progressive income tax schedule is required for equity reasons. Instead, the other objectives of increasing simplicity and efficiency are viewed as being more important. However, while an assessment of the fairness of the tax system requires a value judgment, it cannot be completely separated from the issue of efficiency, in particular if dynamic effects are considered. To the extent that the tax reform raises labour productivity and reduces the scope for unemployment and poverty traps, it also has significant potential to benefit the low-skilled segment of the population. The extent to which this segment of the labour force benefits will thus depend on policies that facilitate demand for low-skilled labour as well as on the educational opportunities that people have to upgrade their human capital.

\section{The sweeping tax reform has reduced taxes on income and increased taxes on consumption}

6. Slovakia's recent tax reform, which came into effect on 1 January 2004, is unique in the sense that the tax rates of the personal income tax (PIT), the corporate income tax (CIT) and the value added tax (VAT) were all set equal to $19 \%$. Before the reform the PIT had a progressive rate structure with - after the basic exemption - five income brackets with marginal tax rates of $10 \%, 20 \%, 28 \%, 35 \%$ and $38 \%$. The corporate tax rate was $25 \%$ (in 2003/2004 after 29\% in 2000/2001 and 40\% before) and the VAT had a standard rate of $20 \%$ and a reduced rate of $14 \%$. Along with these changes in tax rates many exceptions, exemptions and special regimes were eliminated. However the basic personal income tax exemption has not only been preserved but also more than doubled and it is now higher than the minimum wage and around $60 \%$ of the average wage. Taking this exemption into account, together with the income tax deductibility of social security contributions, Figure 1 illustrates the extent to which the marginal effective income tax rate has changed as a result of the reforms.

Figure 1. Effective marginal income tax rates: single tax payer

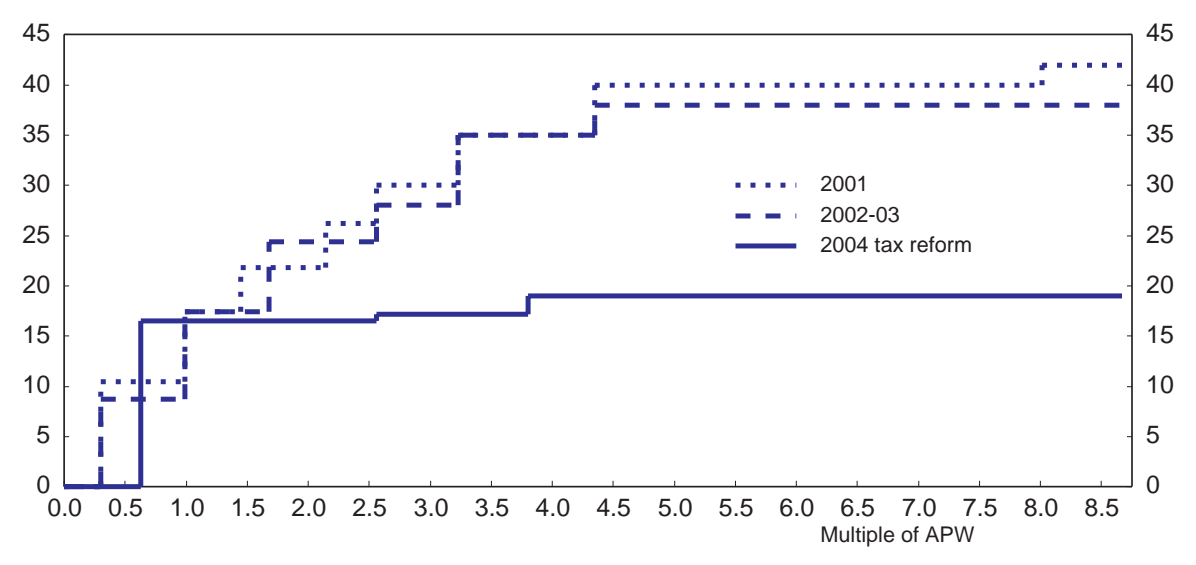

Note: The scale shown on the horizontal axis is based on the 2003 APW of 150000 SKK per year. For 2004 , the two steps in the marginal effective tax rate for workers whose income exceed the basic tax exemption reflect the different income assessment bases for income tax deductibility of health insurance and social security contributions. Source: OECD, Taxing wages database.

7. Although the marginal tax rate remains constant at high incomes, the basic tax exemption ensures that the tax system retains an element of progressivity, with average personal income tax rates rising with 
income (Figure 2, top panel). The negative average tax rate faced by those on moderate incomes results from the refundable child tax credit, and (for families with at least one parent earning half the minimum wage $^{2}$ ) serves to offset the reduction in the child allowance as discussed in more detail below. Average composite tax rates (i.e. including social security contributions) are also progressive but only up to income levels equivalent to 3 times the average wage, at which point the maximum assessment base for social security contributions kicks in and the average composite tax rate becomes slightly regressive (Figure 2, bottom panel).

Figure 2. Average tax rates

Tax paid as \% of gross labour income
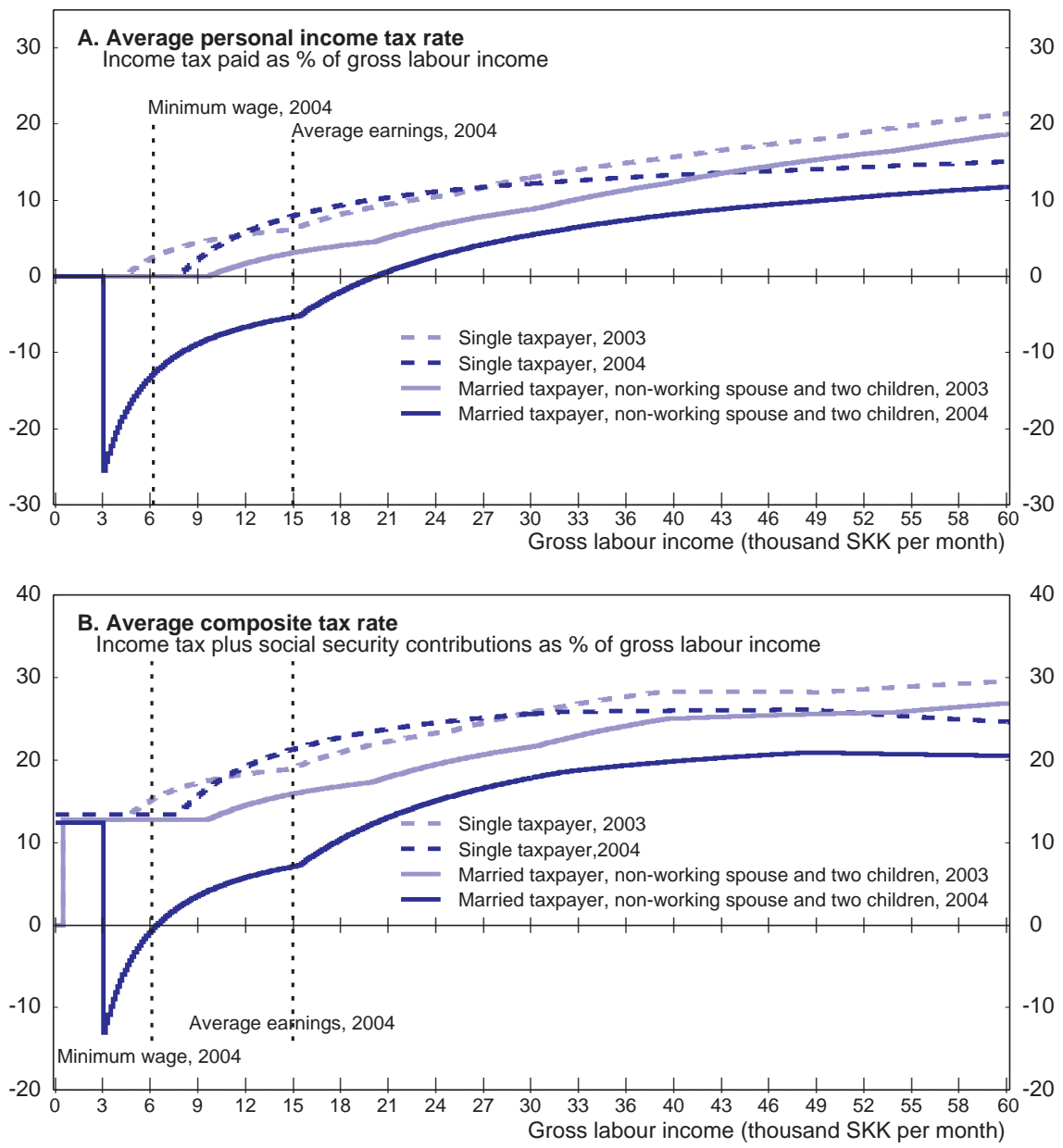

Note: Calculations take into account housing benefits and child allowances but assume that workers are not new to the labour force (i.e. activation allowances are not taken into account). Results do not take into account national minimum wage legislation. As a result scenarios for incomes lower than the minimum wage would be applicable only to part-time workers, of which there are relatively few in Slovakia.

Source: OECD, Taxing wages database.

2. The minimum income threshold for eligibility to the child tax credit is six times the minimum wage over a 12 month period. Thus, a family will become eligible if at least one parent has worked $1 / 2$ time at the minimum wage for a full year. 
8. The tax reform also changed the tax base for property taxation from size to value assessments, eliminated inheritance taxes and the income tax on dividends, and increased excise taxes on tobacco; with the last measure excise taxes became fully harmonised with EU regulations and earlier than required by Slovakia's accession treaty with the EU. Furthermore, in a separate reform overall social security contributions were reduced by 2.4 percentage points and the ceilings for pension and unemployment insurance contributions were increased.

9. The government's broad objectives for the tax reform were: "creation of a business and investment friendly environment for both individuals and companies; elimination of existing weaknesses and distortionary effects of the tax law; and achievement of a high degree of tax fairness by taxing all types and amounts of income equally". ${ }^{3}$ At the same time the tax reform was designed to be revenue-neutral with the tax reductions in the personal income tax (PIT) and the corporate income tax (CIT) being (broadly) compensated by increases in the VAT thus leading to a shift in the tax burden from income to consumption.

10. With this reform Slovakia became the first OECD country to introduce a flat rate personal income tax although other countries in Central and Eastern Europe had introduced such a tax earlier; the first countries were Estonia and Lithuania in 1994 and currently not less than nine countries in Central and Eastern Europe (the three Baltic States, Russia, Serbia, Slovakia, Ukraine, Georgia, and Romania) have a flat rate personal income tax (Table 1).

Table 1. Flat taxes on personal income: an international comparison

\begin{tabular}{lcc}
\hline Country & Tax rate in \% & Year introduced \\
\hline Estonia & 26 & 1994 \\
Lithuania & 33 & 1994 \\
Latvia & 25 & 1995 \\
Russia & 13 & 2001 \\
Serbia & 14 & 2003 \\
Slovakia & 19 & 2004 \\
Ukraine & 13 & 2004 \\
Georgia & 12 & 2005 \\
Romania & 16 & 2005 \\
\hline
\end{tabular}

Source: The Economist.

11. The remainder of this paper examines the effects of the reform on its three objectives: revenue neutrality, simplicity, and economic efficiency. Equity issues are also discussed.

\section{The tax reform has been revenue neutral}

12. The objective of revenue neutrality was met in 2004, the first full year under the new regime. While revenues from the personal income tax and the corporate income tax declined as a share of GDP (from 3.3\% of GDP in 2003 to $2.6 \%$ in 2004 for the PIT and from $2.8 \%$ to $2.5 \%$ for the CIT), revenues

3. See http://www.finance.gov.sk/EN/Default.aspx CatID=118 
from the VAT increased (from 6.7\% of GDP in 2003 to $7.9 \%$ in 2004) so that the total share of taxes in GDP remained practically constant (18.1\% of GDP in 2003 versus $18.0 \%$ in 2004). ${ }^{4}$ It is unclear at this stage to what extent tax arrears have been affected by this reform. The reduction of personal and corporate income tax rates and the simplification of the tax code should have reduced tax arrears.

\section{... and has made the tax system much simpler}

13. With respect to simplicity, the new Income Tax Act radically simplified the taxation of both personal and corporate income. The introduction of a unified VAT rate was a further simplification. The reform not only simplified tax rates but also eliminated most tax expenditures. ${ }^{5}$ As a result, the tax system is now much simpler and more transparent and administrative costs are lower for both the tax administration and tax payers.

14. The introduction of a uniform tax rate between labour and capital income also increased simplicity and reduced the problem of tax evasion where people declare labour income as capital income (for example, owners of firms who are working in the firm or managers). This problem arises in dual income tax systems where capital income is taxed at a flat (and relatively low) rate while other income remains taxed at progressive rates. However, since labour income remains subject to payroll taxes (at least up to the income threshold of 3 times the APW), there are still incentives for some self-employed persons to convert employment income into capital income in order to evade social security contributions.

\section{Economic efficiency should improve over the longer term}

15. Generally speaking, the tax reform reduced taxes on income and shifted more of the tax burden onto consumption. ${ }^{6}$ These changes were expected to increase incentives to work and save and thus raise the growth potential of the economy. Replacing the progressive income tax by a flat rate tax should also stimulate human capital formation as the return on this investment is not taxed at higher rates. However, these efficiency effects depend on the responsiveness of economic agents to changes in taxation and this depends not only on the tax system but also on its interaction with labour market regulations as well as the social welfare system. In the following sections the effects on labour and capital are discussed in more detail.

\section{Effects on the labour market should be positive}

16. The employment incidence of a tax depends on the extent to which the tax is "shifted forward" onto producers' real labour costs (production wage). "Shifting forward" occurs if workers resist reductions in their real take-home pay, either because they demand wage increases in response to an employee tax, or because they resist wage cuts in response to an employer tax. In this case the tax increases labour costs and

4. 2004 tax revenue figures are estimates from the Financial Policy Institute which is part of the Ministry of Finance.

5. From the perspective of tax revenues, the most important tax exemptions to be abolished were: (i) various allowances on interest and capital income; (ii) employers' additional (private) pension insurance contributions; (iii) employee income from companies' social funds (the tax rate on this income was increased from $10 \%$ to the standard rate of 19\%); (iv) the tax allowance for corporate gift expenditure. The abolishment of other exemptions was aimed primarily at eliminating distortions rather than widening the tax base. At the same time many investment stimuli (tax breaks) were also eliminated as part of Slovakia's accession to the EU.

6. While income taxes were reduced for most taxpayers, some tax-payers did end up with a higher tax burden. For example, Figure 2 illustrates that the average personal income tax rate increased very slightly for single taxpayers earning between 12000 and 27000 SKK per month. 


\section{ECO/WKP(2005)35}

reduces the demand for labour. If instead the tax is borne by workers who accept a reduction in their takehome pay, labour costs do not rise and labour demand is not affected. However, workers may respond to the fall in wages by reducing their labour supply; in this case employment also falls. As the labour demand elasticity is generally larger than the labour supply elasticity, the higher the degree of forward-shifting of the tax the larger the negative employment effects of a labour tax.

17. The degree of tax shifting onto product wages is likely to be inversely related to the extent of labour-market flexibility. Thus inflexible labour markets will tend to have more forward-shifting of labour taxes and more negative employment effects. Low competition in the labour market (inflexibility) may be the result of stringent labour market regulations, union bargaining power, or "insider" behaviour of employed workers.

\section{...by increasing demand for labour}

18. Demand for labour depends partly on the cost of labour, and partly on labour market flexibility. Despite the recent tax reform, labour taxes remain relatively high in Slovakia. However, the new Labour Code, introduced in 2003, has resulted in a much more flexible labour market. Changes included: an increase in the working week to up to 48 hours (including overtime); flexible setting of working hours and rest times; flexible part-time arrangements; a provision for indefinite repetition of fixed term contracts; a cut in severance pay; and a considerable easing of the conditions under which workers can be dismissed. As a result, Slovakia is now ranked as having a relatively flexible labour market according to the OECD's indicator of Employment Protection Legislation, particularly for temporary workers. The new labour code also weakened the powers of the trade unions and worker councils. Whereas under the 2001 rules they had an effective veto power over organisational changes and worker dismissals, under the 2003 law unions need only be notified in advance.

\section{...although total taxes on labour remain high}

19. These changes should reduce the degree of "shifting forward" of labour taxes into producers" real labour costs and thus increase labour demand. However, for very low-skilled workers (whose unemployment rates are highest), the minimum wage sets a floor for shifting labour taxes onto workers. This raises questions as to whether the combination of the minimum wage and the high tax on labour may be suppressing demand for very low-skilled labour in the high unemployment regions of Slovakia.

20. For Slovakia as a whole, average wages are still relatively low compared to those in the other Visegrad countries $^{7}$ (Figure 3 - top panel), but this is largely explained by Slovakia's lower productivity levels. The minimum wage in Slovakia is also the lowest of the four Visegrad countries, although only in absolute terms. As a percentage of the average wage the total minimum cost of labour (including employers' social security contributions) ranks around the middle of the OECD (Figure 3 - bottom panel) and is higher than that in Poland and the Czech Republic. In practice, however, the effective minimum wage is even higher. This is because the minimum wage varies along a 6-level scale (from 1.0 to 2.0 times the absolute minimum wage, increasing in 0.2 increments) according to the skill-level required for the position. Thus, since the minimum wage shown in Figure 3 is the lowest rung, the effective minimum wage may be significantly higher. Unfortunately, no data is available on the proportion of workers for whom the 6-level scale is binding. However, data on the distribution of wages indicates that while only $3 \%$ of full-time workers earn the bottom rung minimum wage, $45 \%$ of full-time workers earn two times the absolute minimum wage (i.e. the top rung on the minimum wage scale) or less. ${ }^{8}$ While the proportion of

7. Czech Republic, Hungary, Poland and Slovakia.

8. Wage zones of average monthly gross salary in 2003 (by working time and gender), Slovak Statistical Office. 
these workers whose wages are set according to the minimum wage scale is not known, it seems likely that the multi-scale minimum wage is binding for some employers, particularly in the Eastern regions of Slovakia where productivity is lower and where workers' reservation wages are likely to be the lowest. ${ }^{9}$

Figure 3. The cost of labour $2002^{1}$

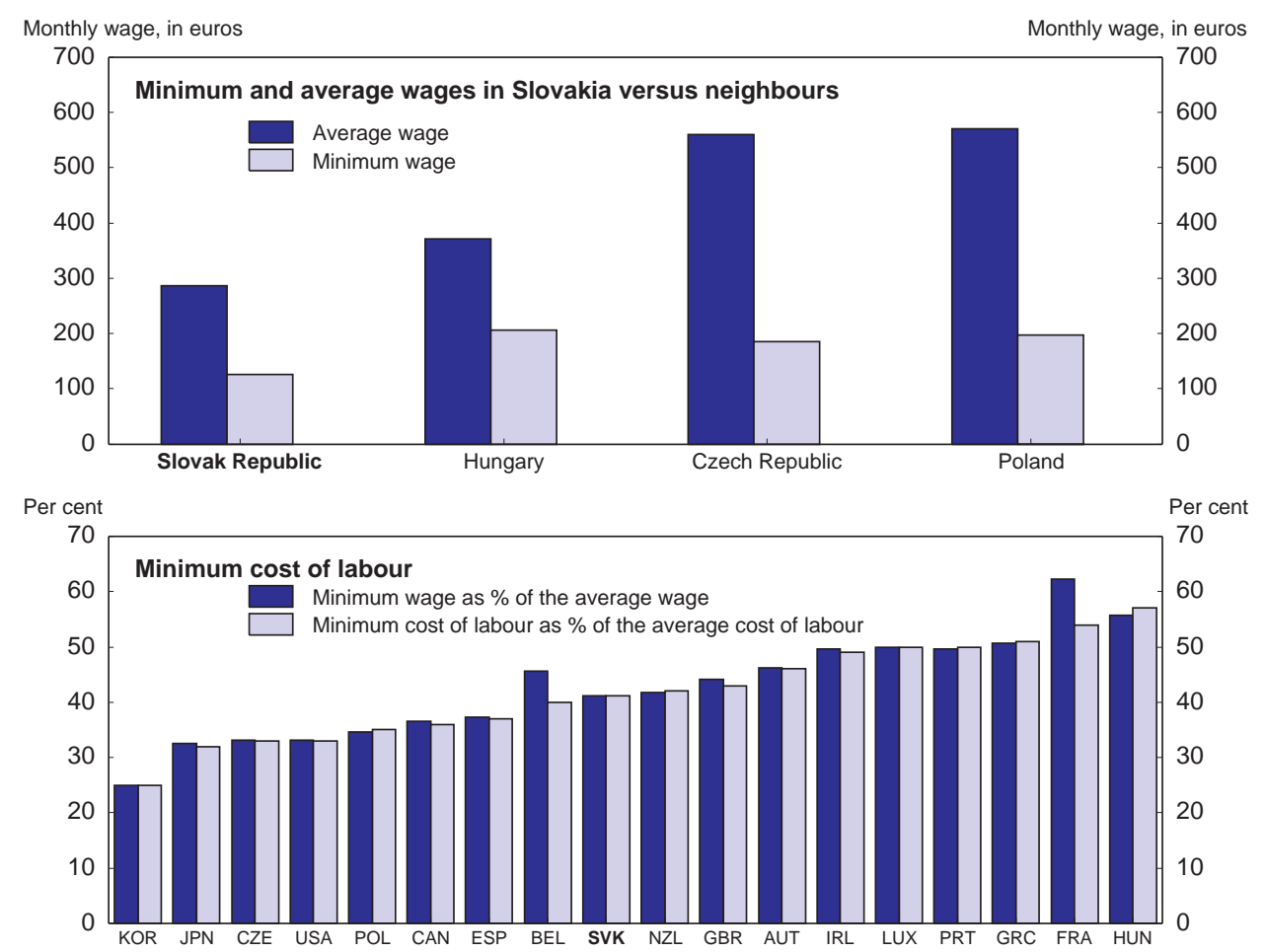

1. Slovak Republic data are for 2004. All other countries are 2002.

Source: OECD, Benefits and Wages 2004 (for 2002 data). Provisional figures for Slovakia for 2004; Taxing Wages, 2004

21. The cost of low-skilled labour depends not only on the minimum wage, but also on payroll taxes, which (in the form of high social security contribution rates) are listed by Slovak firms as one of the top three factors impeding business development. ${ }^{10}$ Even after recent cuts, overall payroll taxes remain the highest of the Visegrad countries and employer social security contributions continue to add around $35 \%$ to the average wage (see Table 2). For low-wage labour in particular, Figure 4 indicates that the average tax wedge in Slovakia is higher than both the OECD and EU-15 averages. ${ }^{11}$

9. Even if the minimum wage is appropriate in Bratislava, and other western regions, where productivity levels are generally higher, it may be too high in the Eastern regions, where both living costs and average productivity levels are much lower.

10. The other two are inadequate law enforcement and corrupt administrate practices (WEF, 2004).

11. The average tax wedge on labour is also very high for single workers earning $100 \%$ of the APW, although in this case it is slightly below the EU15 average. 
Table 2. Compulsory social security contributions as \% of gross income

\begin{tabular}{lccc}
\hline & Employee & Employer & Total \\
\cline { 2 - 4 } Health insurance & $\mathbf{4 . 0}$ & $\mathbf{1 0 . 0}$ & $\mathbf{1 4 . 0}$ \\
Social insurance, of which: & & & \\
$\quad$ Sickness & 1.4 & 1.4 & 2.8 \\
$\quad$ Retirement & 4.0 & 14.0 & 18.0 \\
$\quad$ Disability & 3.0 & 3.0 & 6.0 \\
Unemployment & 1.0 & 1.0 & 2.0 \\
Accident $^{1}$ & - & 0.8 & 0.8 \\
Employers' guarantee $^{2}$ & - & 0.25 & 0.25 \\
$\quad$ Reserve Fund of the $\mathrm{SP}^{3}$ & - & 4.75 & 4.75 \\
Total & $\mathbf{1 3 . 4}$ & $\mathbf{3 5 . 2}$ & $\mathbf{4 8 . 6}$ \\
\hline
\end{tabular}

1. After a transition period, the accident insurance rate will depend on the category of risk associated with the employer's activities.

2. This is insurance against the employers' insolvency so that employees' claims can be satisfied.

3. This funds the PAYG pillar of the pension insurance.

Source: Ministry of Labour, Social Affairs and Family of the Slovak Republic.

Figure 4. Tax wedges on low-wage labour, international comparison ${ }^{1}$ As per cent of gross labour costs, $2003^{2}$
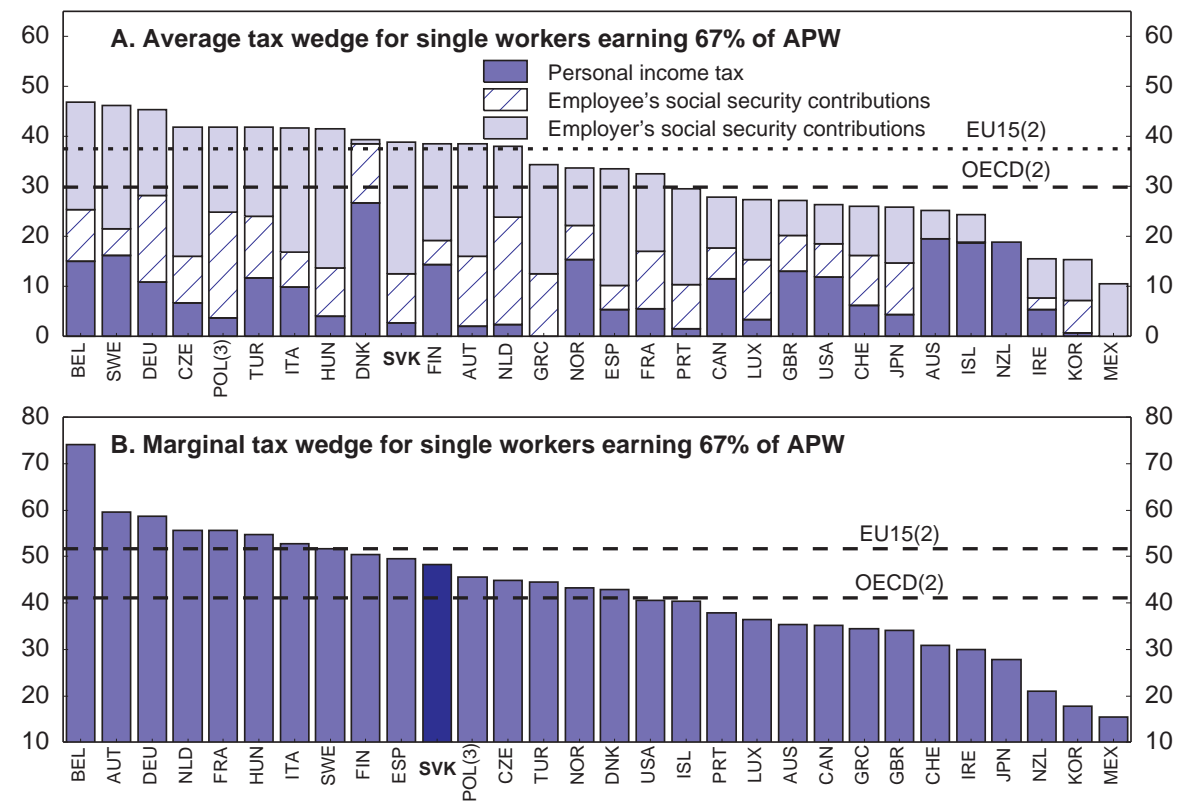

1. Average and marginal tax wedges for a single individual without children at the income level of $67 \%$ of APW or estimated APW wage levels.

2. Weighted average using 2000 GDP (PPP-adjusted)

3. A submission was not received from this country and consequently the tax/benefit structure for this country has been updated using external sources. Given the potential for error, the reader should use caution in interpreting the results for this country.

Source: OECD, Taxing Wages, 2004. 
22. The high level of total payroll taxes is likely to be the greatest hindrance to employment growth in smaller, less productive firms (e.g. in the services sector), and particularly in the Eastern regions of Slovakia where productivity is lower. It is likely that the high tax wedge also contributes to informal employment. Given the fact that the tax on capital is much lower than the overall tax on labour, it is perhaps not surprising that the new FDI firms are engaging primarily in capital-intensive activity rather than the creation of low-skilled jobs. Indeed, some researchers have found evidence of significant capitallabour substitution in economies with high tax wedges. ${ }^{12}$

\section{... and should be further reduced by cutting social security contributions for low-skilled workers}

23. The link between high tax wedges and low employment is well documented, ${ }^{13}$ and there is evidence that this negative relationship is the most severe for low-skilled workers (see Box 1). Thus, and in light of Slovakia's very high unemployment rate, ${ }^{14}$ the 2005 OECD Economic Survey of the Slovak Republic recommended that the government should prioritise reductions in the cost of low paid labour in order to boost the creation of jobs that require low skill levels. The survey argued that this could be done by reducing the cost of low paid labour via substantial reductions in employers' social security contributions for low-income earners. Since the objective of these cuts would be to raise formal sector employment among those with low skills, the cuts should be made to employers' social security contributions, rather than employees' contributions. This would ensure that cuts reduce the labour cost of workers who earn around the minimum wage, thus expanding demand for this category of employee. However, employers' pension contributions should be retained, since these contributions directly affect the employee's future benefit entitlements. Instead, the health insurance contribution of $10 \%$ could be cut, together with other items (sickness, disability, unemployment, Reserve Fund of the Social Insurance Company) where there is no link between individual contributions and subsequent entitlement. ${ }^{15}$ Careful targeting should limit the cost of these cuts significantly and the remaining cost should be funded by expenditure restraint in less urgent areas such as industrial and agricultural subsidies. An alternative way to reduce the cost of low-skilled labour would be to reduce the minimum wage. However, this may be less politically feasible even if other policies were introduced at the same time to mitigate the impact on workers' net incomes. ${ }^{16}$

12. E.g., Daveri and Tabellini (2000).

13. See for example,, OECD (2003), Carey (2003), World Bank (2005).

14. The Slovak unemployment rate, as measured by the HLFS, has fluctuated around $17-19 \%$ in recent years, although it recently fell to $16.2 \%$ in the second quarter of 2005 - its lowest level since 1999.

15. Indeed, many OECD countries fund public health expenditures through general taxation, rather than health insurance contributions.

16. The impact of a reduction in the minimum wage on workers' incomes can be offset by the introduction of an earned income tax credit for individuals. Indeed, the Slovak government has already proposed the introduction of such an earned income tax credit. If introduced, it would increase the net incomes of low income workers. The resulting fall in the tax wedge for low income workers would further increase the motivation for the unemployed to seek work in the formal sector. However, unless the minimum wage was cut at the same time, the cost paid by employers of low-income workers, and therefore the demand for labour, would be unchanged. 


\section{Box 1. The case for cutting payroll taxes for low skilled workers}

Not only is the tax wedge on labour higher in Slovakia than in many other OECD countries, but there is also a relative abundance of low-skilled workers. Although the Slovak minimum wage is not high in absolute terms (Figure 3), it is now more than four times higher than the basic level of social assistance, ${ }^{1}$ suggesting that the minimum wage may be more binding in Slovakia than in other countries where replacement rates are higher. These factors suggest that the tax wedge might be more harmful to employment in Slovakia than in Western Europe.

Some support for this idea has been provided by a recent World Bank study. ${ }^{2}$ Using a pool of annual data for eight of the new EU entrants ${ }^{3}$ for the period 1996-2003, the World Bank estimated that, for a given GDP growth rate, each percentage point increase in the tax wedge is associated with a decrease in employment growth by 0.5 to 0.8 percentage points. While the data limitations suggest that this result should be interpreted carefully, ${ }^{4}$ it does suggest a strong and significant negative relationship between the tax wedge and employment in the EU-8 countries.

The Slovak authorities also acknowledge the need to cut social security contributions, although they argue that fiscal constraints mean that this must be delayed until 2007 at the earliest. However, most proposals have involved cuts to payroll taxes across the board. If instead, the cuts were targeted specifically to low-income workers, the employment benefits could be maximised at a much lower fiscal cost. This is because (formal sector) labour supply is more elastic in the vicinity of the minimum wage than at higher wages. Thus, the upward shift in labour demand, in response to a cut in payroll taxes, results in a proportionately greater impact on employment of employees who are paid around the minimum wage than for other employees. ${ }^{6}$ It is also worth noting that Slovakia is one of only a few OECD countries where even very low wages are subject to full contributions (from both employer and employee).

The unavoidable downside to implementing such targeted reductions in the labour tax wedge is the incentive effect of targeting - since it results in higher marginal effective tax rates (METRs) in the income range over which the measures are withdrawn. However, while higher METRs may reduce the overall increase in the number of hours worked, notably for part-time workers, this is a much less serious problem in Slovakia than the current prevalence of unemployment traps, particularly in the high unemployment regions where the gap between labour demand and supply is very wide. Besides, the distribution of earners in Slovakia is relatively wide, suggesting that careful targeting design could ensure that the targeted measures be withdrawn at income levels still well below the APW, ensuring that incentives for skill acquisition would remain.

To illustrate the affordability of targeted labour tax cuts, consider the fact that only around $7 \%$ of workers earned less than 9000 SKK per month in 2003. If the average employer social security contribution for this group was reduced from $35 \%$ to $18 \%$, the direct reduction in social security revenues would be only around $0.7 \%$ of GDP. ${ }^{7}$ However, there are a number of potential positive impacts that would mitigate this cost further. First, the lower tax wedge should partly finance itself through higher output and higher employment (including higher tax and social security revenues). Second, to the extent that formal employment would grow in the personal services sector, then VAT revenues would also increase. Third, even if some of the new employment is simply a shift from the informal to the formal market, this would have indirect benefits, including better training opportunities for low-skilled workers in the formal economy and better legal protection of these workers.

Substantial targeting of cuts in labour taxes for low-income earners has been successfully used in other OECD economies. For example, France introduced rebates on social security contribution rates for wages close to the minimum wage in 1993, and has subsequently extended both the range of wages concerned by these rebates and the size of the rebates. Although it is difficult to estimate precisely the number of jobs created by this policy, employment of low-skilled workers has strongly improved and total net job creation has also been strong. Belgium also introduced sizeable targeted cuts in employers' social security contributions after 1999 and the impact on employment was estimated to be significant. ${ }^{9}$ As a result, these two countries have managed to reduce the minimum cost of labour without cutting the minimum wage (see Figure 3 - bottom panel). A targeted system of earned income tax credits in the UK has produced similarly positive results for employment rates of low skilled workers, although this has worked mainly through increasing incentives to work (which are already strong in Slovakia) rather than by increasing demand for low skilled workers.

1. In early 2005 the minimum wage was 6500 SKK compared with social assistance for a single person of 1530 SKK. However, this can be raised to around 3000 SKK by qualifying for the activation allowance associated with undertaking volunteer work in municipalities. 
2. World Bank (2005).

3. The four Visegrad countries (Czech Republic, Hungary, Poland and Slovakia) plus the three Baltic states (Estonia, Latvia and Lithuania) and Slovenia.

4. The authors acknowledge that the small sample size and the small number of variables and related possibility of omitted variables could have biased the results.

5. The range of estimates using data for the wider OECD group of countries is usually slightly lower, ranging from 0.11 to 0.55 (e.g., see De Haan et al (2003) and Nickell (2003) for literature reviews).

6. Carey (2003).

7. These calculations are back-of-the-envelope estimates based on the 2003 distribution of wages. The $18 \%$ contribution rate after the cuts retains only the employers' pension contribution, the employers' guarantee, and the accident contribution (see table 1). With an unchanged minimum wage, a reduction in employer social security contributions to around $18 \%$ would reduce the minimum cost of labour from $41 \%$ of the average wage to around $31 \%$.

8. OECD $(2005 b)$.

9. Carey (2003).

\section{Labour supply is also boosted by the reforms}

24. The effects on labour supply depend on the change in the tax wedge and on the elasticity of labour supply. ${ }^{17}$ With the recent tax reform most people experienced falls in both their average tax rates (Figure 2) and their marginal tax wedge (Figure 5).

25. Figure 5 illustrates that the largest falls in marginal tax wedges occurred for low-income married workers, for workers earning around $2-2 \frac{1}{2}$ times the APW, and for workers earning above 3 times the APW. These lower marginal tax rates stem from a combination of factors. First, the tax exempt income threshold has been significantly increased and a married taxpayer whose spouse does not have an income can now deduct the same amount again for their spouse. ${ }^{18}$ Second, the conversion of the previous incomedependent child allowance into the combination of a universal child benefit and an earned-income tax credit has reduced marginal tax rates of workers with children. ${ }^{19}$ Finally, the flat rate of $19 \%$ has particularly benefited workers earning between 1 and $2^{1 / 2}$ times the APW. On the other hand, workers earning a bit more (i.e. between $2 \frac{1}{2}$ and 3 times the APW) now face higher marginal tax wedges, due to the increase in the maximum income threshold for making social security contributions. At the very upper end of the income distribution (higher than 3 times the APW) marginal tax wedges have fallen to $19 \%$ as a result of the lower single tax rate compared with $38 \%$ before the change. ${ }^{20}$

17. A reduction in the income tax increases labour supply if the substitution effect dominates the income effect: the tax reduction increases the price of leisure relative to work and thus encourages work effort (substitution effect); at the same time if consumers have a targeted flow of consumption, the lower income tax increases the disposable income of workers so that less work efforts are needed to achieve the same income (income effect). The substitution effect depends on the marginal tax rate, the amount of the last unit of income earned, while the income effect depends on the average tax rate, the total amount of tax taken out of income. In the empirical literature it has been found that for married women and lone mothers the substitution effect clearly dominates the income effect (i.e. labour supply elasticity with respect to the net wage has a positive sign) while men's labour supply elasticity is small or slightly negative (i.e. in the latter case the income effect dominates). See Leibfritz et al. (1997).

18. The tax deductible per individual taxpayer more than doubled from 38760 SKK in 2003 to 80832 SKK in 2004. Taxpayers whose spouses do not have their own income are now able to deduct the spouse's full deductible from their own income, whereas the deductible for spouses was only 12000 SKK in 2003.

19. In 2004 a flat child allowance of 500 SKK per child per month was introduced regardless of the family income. Working parents also receive a refundable tax credit equal to $400 \mathrm{SKK}$ per month. This compares with the 2003 allowance which varied between $270-890$ SKK per child per month depending on the child's age and the family income.

20. Moore (2005) suggests that only around 1\% of workers earn more than 3 times the APW, although this estimate should be treated cautiously. 
Figure 5. Marginal tax wedge on labour ${ }^{(1)}$ in Slovakia Per cent
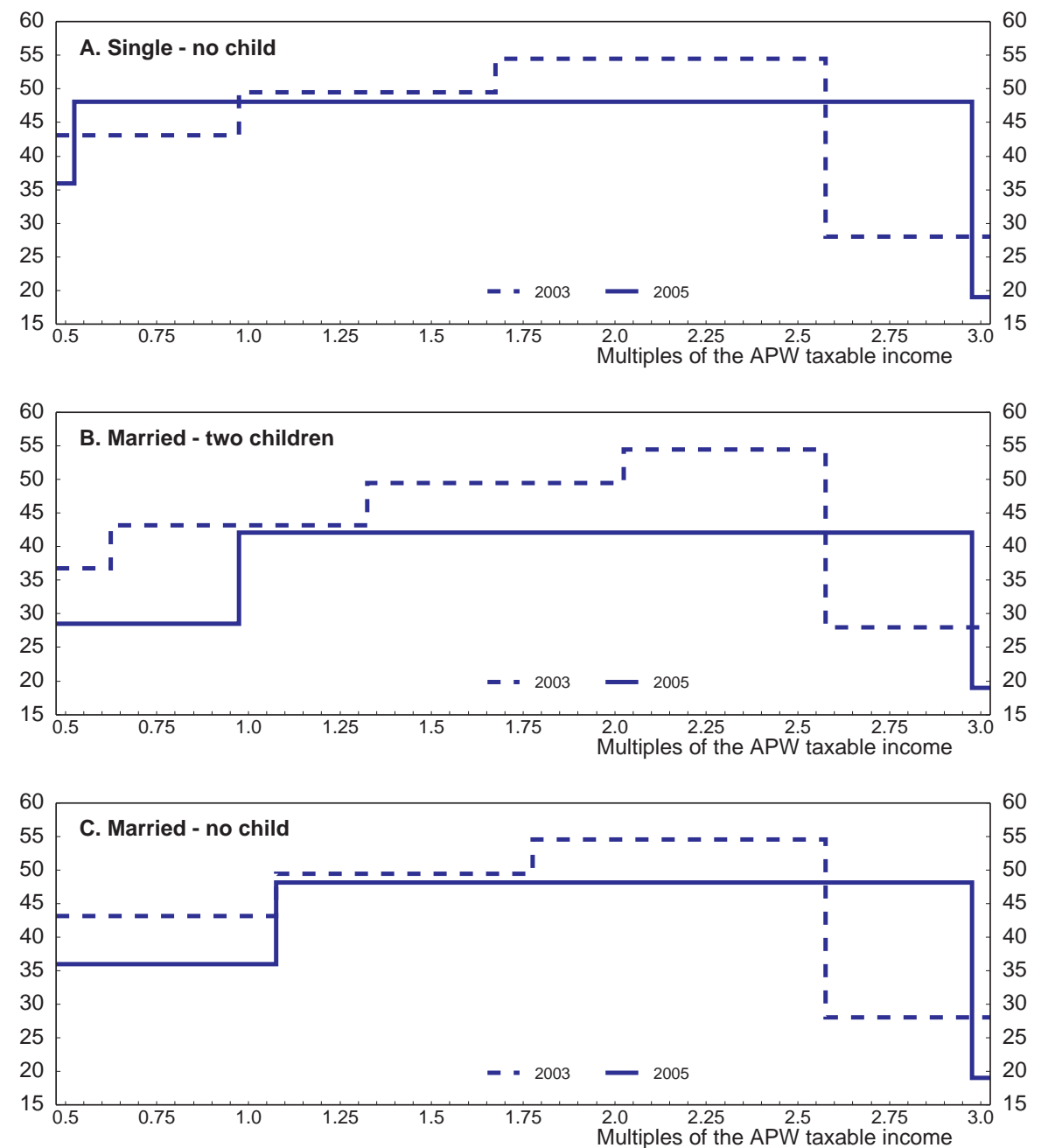

1. Tax wedges, which show the gap between labour costs to the employer and the corresponding net take-home pay of the employee, are calculated as the sum of personal income tax, employee plus employer social security contributions and any other payroll taxes, as a percentage of labour costs (scenarios assume a zero income of any spouse).

Source: OECD, Taxing wages, 2003 and 2005.

26. Some impact on formal sector labour supply may also stem from the fact that the reduction of the personal income tax makes it easier to comply with the tax code allowing some employment to shift from the informal to the formal sector. However, continuing high social security contribution rates mean that the total tax wedge on labour declined only moderately, suggesting that the effects of tax cuts alone on labour supply are probably small. Once the effect of cuts in social benefits is also taken into account, the overall effects of the fiscal system on labour supply are much larger. 
27. Indeed, analysis that takes into account both the tax and social security reforms, suggests that unemployed people in Slovakia now have significantly greater incentives to work. This has been achieved partly through lowering income tax rates, but more importantly by cutting social assistance benefits. The introduction of universal child allowances (as discussed above) and a range of pro-work initiatives have also helped to "make work pay". Importantly, social assistance benefits are now reduced less abruptly if the recipient earns labour income.

28. The impact of these reforms can be summarised by measuring that part of in-work earnings that is, upon entering employment, "taxed away". For a jobless person entering work, this "tax on re-employment", or average effective tax rate (AETR) ${ }^{21}$ has now been significantly reduced, although more so for some groups than others (Figure 6). Not surprisingly, the highest AETRs in Slovakia are for people who have only recently become unemployed and who are eligible for unemployment insurance (Figure 6panel A). Yet all three cases shown in the figure indicate that "work pays" whereas previously the AETRs were higher than $100 \%$ for some people.

29. Once unemployment insurance runs out, or for individuals who are not eligible in the first place, AETRs are now significantly lower. The cuts in AETRs have been particularly dramatic for one-earner couples (as illustrated in Figure 6 - panel B) as well as for single people and lone parents (not illustrated). As in other OECD countries, AETRs are even lower for second income earners who are returning to work (Figure 6 - panel C). Similarly, marginal effective tax rates (METRs) - for employed workers increasing their working hours or moving to higher paying jobs - have also been significantly reduced.

30. The stronger incentives to work stem in large part from the relatively low level of social assistance that is now offered, together with the fact that social assistance is now reduced less abruptly if the recipient begins to earn labour income. Figure 7 illustrates the extent to which net replacement rates for the long-term unemployed have fallen. Evidence that work incentives are now significant is also provided by the fact that, in regions of high long-term unemployment, the supply of workers seeking low-skilled volunteer jobs (which entitles workers to the activation allowance of 1500 SKK per month - equivalent to just under $1 / 4$ of the minimum wage) has outstripped the ability of municipalities to provide such jobs. ${ }^{22}$ Anecdotal evidence suggests that for many municipal volunteers, this is the first work they have ever done. Thus for these people there is much pressure to take up any available job in order to survive. The fact that labour supply exceeds labour demand even for these volunteer jobs highlights the fact that not all longterm unemployed are able to take advantage of the income supplement that the activation allowance permits and emphasises the need for accompanying measures to promote labour demand (as discussed above).

21. AETRs are determined by the amount of unemployment and other social benefits that are lost as well as the tax burden on in-work earnings.

22. Note that the marginal effective tax rates discussed above already incorporate the impact of this "activation allowance", so incentives to take on 'proper' work remain. 
Figure 6 Effective tax rates for jobless people moving into work

2002, different working hours, in percent ${ }^{(1)}$

Transition into full-time work; earnings $=$ APW
Transition into part-time work; earnings $=2 / 3$ of APW
Transition into part-time work; earnings $=1 / 2$ of APW
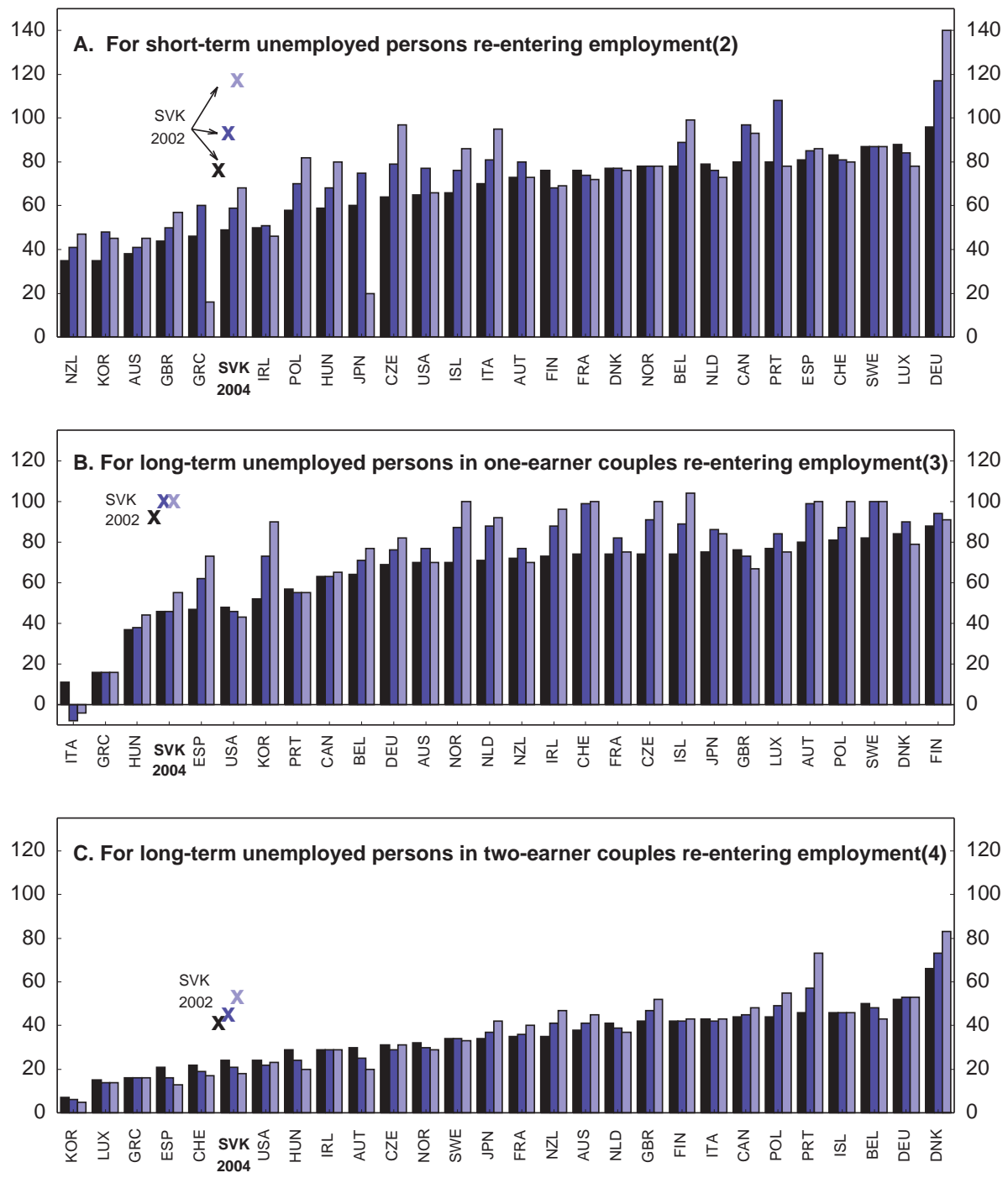

1. 2002 data refer to the situation as of 1 July 2002 for all countries. 2004 data for Slovakia refer to 1 September 2004. The reforms can thus be seen to have moved Slovakia significantly to the left, towards the lower end of the range of effective tax rates among OECD countries from positions in 2002 where Slovakia was towards the higher tax range in the OECD.

2. The jobless person is assumed to have earned an average wage in the previous job and to receive initial rates of unemployment benefits (following any waiting period). The spouse is employed full-time in a low-paid job earning $2 / 3$ of the average wage. There are two children aged 4 and 6.

3. The jobless person receives no unemployment insurance benefits but is entitled to social assistance. Wages following the transition into work correspond to the APW level so a half-time job would pay $50 \%$ of the APW. In-work or activation allowances are also available. The spouse is assumed to be inactive with no earnings. There are two children aged 4 and 6 .

4. Same as Panel B except that the spouse is assumed to have full-time earnings equal to $67 \%$ of APW.

Source: OECD, Benefits and Wages, 2004 (for 2002 data). Provisional estimates using OECD tax/benefit models for Slovakia for 2004. 
ECO/WKP(2005)35

Figure 7. Net replacement rates for two child families in long-term unemployment, $2002^{1}$

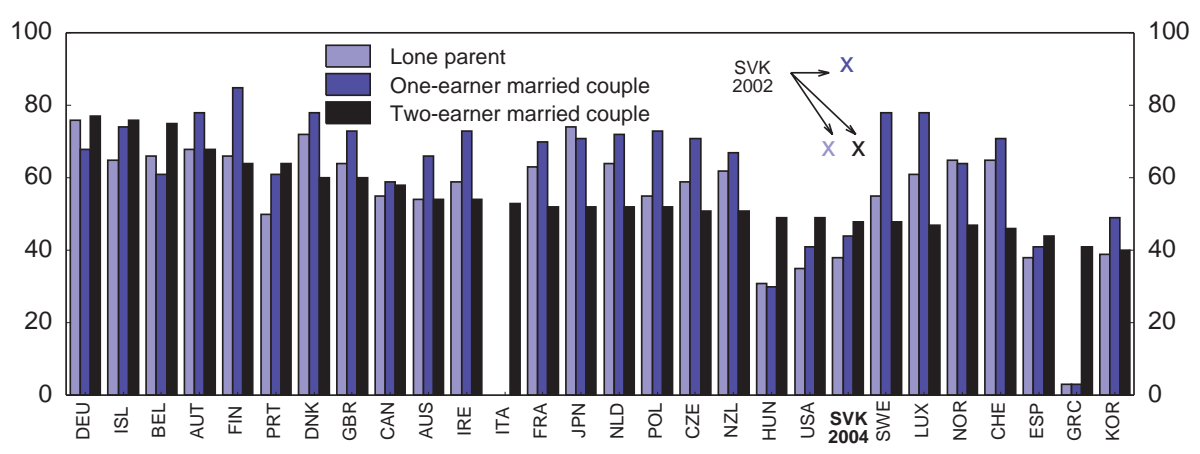

1. Data refer to 1 July 2002 for all countries. 2004 data, for Slovakia, refer to 1 September 2004. Results are net incomes as a percentage of the net earning levels of an APW earner. Includes unemployment benefits, social assistance, family and housing benefits in the $60^{\text {th }}$ month of benefit receipt. For couples the percent of APW relates to the primary income earner only; the second spouse is assumed to have no earnings in a one-earner couple or to have full-time earnings equal to $67 \%$ of APW in two-earner couples. Children are aged 4 and 6.

Source: OECD, Benefits and Wages, 2004 (for 2002 data). Provisional estimates using OECD tax/benefit models for Slovakia for 2004.

31. Given the government's goal to "make work pay", these cuts in net replacement rates were an inevitable consequence of reducing the very high marginal tax rates (often higher than 100\%) that many welfare recipients faced prior to the reforms. Similarly, while it is clear that the reforms have resulted in higher net incomes for those single taxpayers earning more than the minimum wage, some very low income workers are now worse off, particularly those with large families (Figure 8).

32. The pension reform increases incentives to work for older workers who have in the past withdrawn from the labour market at a relatively early age. The retirement age is being progressively increased and will reach the target age of 62 by 2006 for most men and by 2014 for all women. ${ }^{23}$ In addition, the implicit tax on continued work for those past the retirement age has been reduced, thanks to the pension reform. One concern with the new pension rules, however, is that they may be too generous in their provision for early retirement for upper-income workers. ${ }^{24}$

23. Prior to the recent reform the normal retirement age was 60 for most men (but as low as 55-58 for men in hazardous or arduous work) and 53-57 for women (depending on the number of children they had raised).

24. See OECD $(2005 a)$. 
Figure 8 Labour income and net income
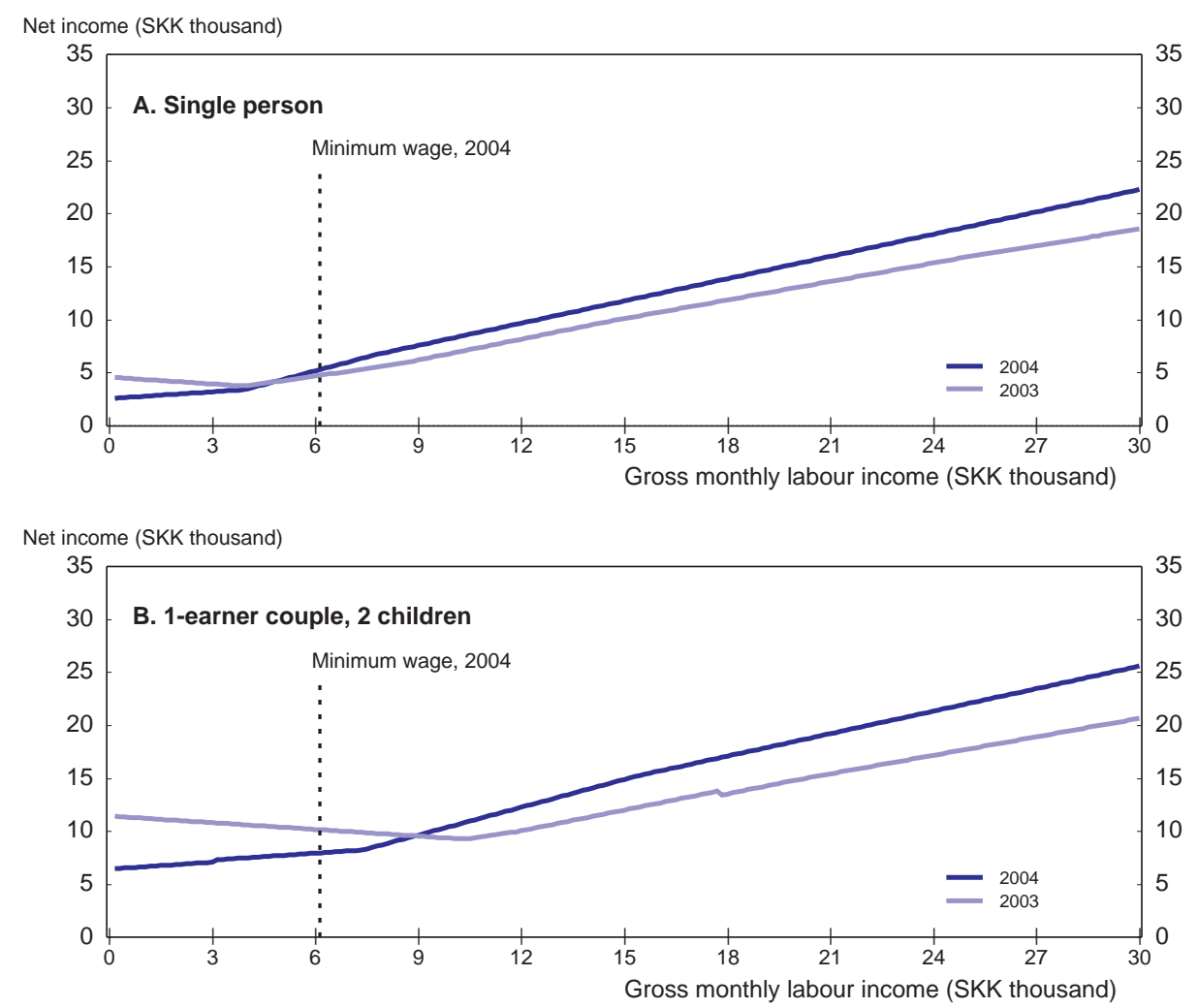

Source: OECD, Benefits \& Wages, OECD Indicators.

\section{The tax reform improves capital formation}

33. When examining the effects on saving and investment one has to distinguish between the effects on the level of capital formation and on the allocation of capital which affects capital productivity. With respect to the level of capital formation, this is likely to be boosted, given that the tax reform has significantly reduced the statutory taxes on capital, and has increased depreciation allowances. With respect to the allocation of capital, this should now be more efficient, since the tax system is now more neutral with respect to the return on investments funded by debt versus equity. However, investments which are financed by retained earnings face double taxation (at the corporate level and the household level by way of the capital gains tax), suggesting that the overall allocation of capital could be made more efficient by eliminating or modifying the capital gains tax.

34. The tax reform has improved the overall incentives for business investment in several respects. First, the corporate income tax has been more than halved since 1999 from $40 \%$ to $19 \%$ and is now relatively low in comparison with other countries, although some countries have even lower rates (Figure 9). The corporate income tax rate is now equal to the marginal personal income tax rate, including the tax rate on interest income. 
Figure 9. Statutory corporate income tax rates on retained profits, 2004

\section{Percent}

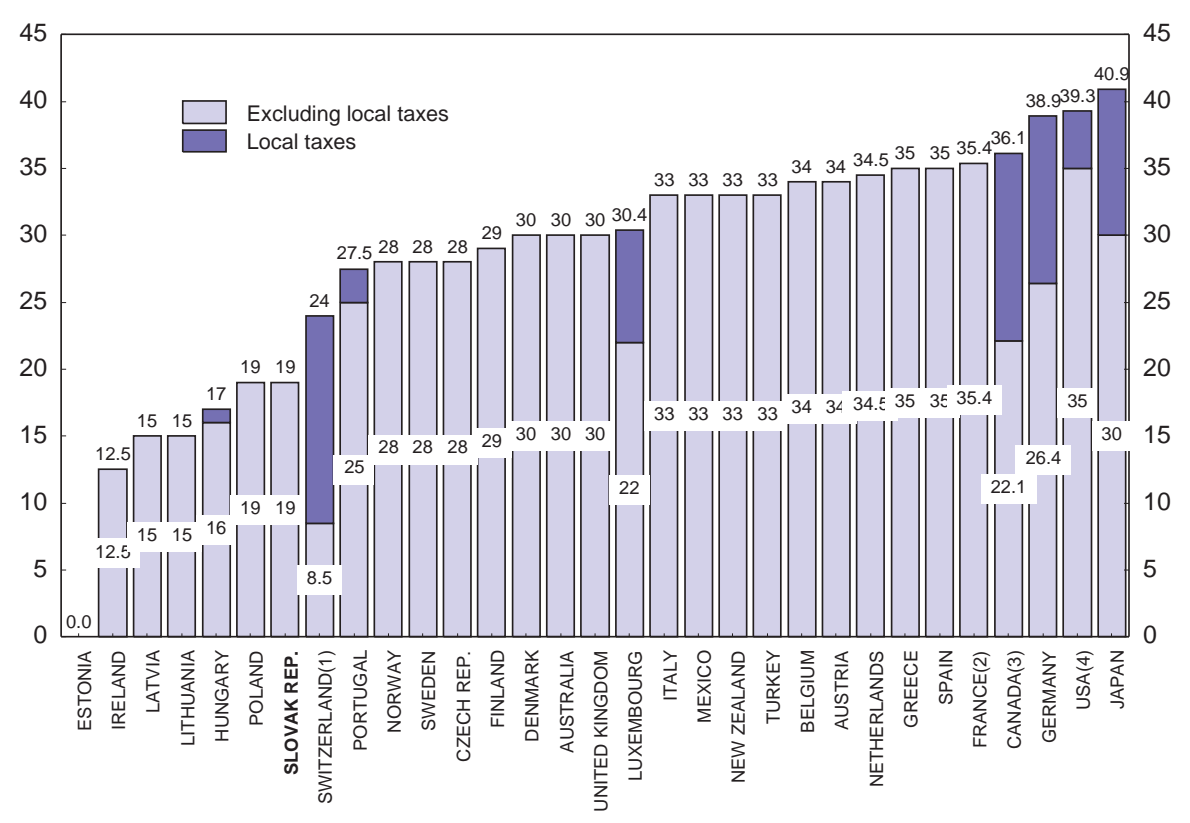

1. Zurich.

2. Excluding local business tax (taxe professionnelle) but including the $3 \%$ surtax. The surtax will be eliminated in two steps in 2005 and 2006.

3. Ontario.

4. State of New-York.

Source: OECD and German Ministry of Finance.

35. Second, dividend taxation has been abolished, eliminating the double income taxation of dividends. Third, the rules pertaining to the carrying forward of business losses have been eased, with the new tax law permitting losses to be deducted from taxable income over a 5 year period, with unequallysized annual write-offs now permitted. Finally, depreciation allowances for industrial buildings were also increased.

36. According to calculations by the German research institute ZEW, the combination of these reforms reduced the effective average and the effective marginal tax rates on investment in Slovakia to internationally low levels (see Tables 3 and 4 and Figure 10). This should provide further incentives for investment, including FDI, and to entrepreneurial activity in general in addition to the positive signalling effect from the cut in the statutory corporate tax rate. ${ }^{25}$

25. Both the effective average tax rates (EATR) and the effective marginal tax rates (EMTR) are based on model calculations using parameters of tax legislation, in particular, the statutory corporate tax rate and depreciation allowances. The EATR measures the effective corporate tax burden on profitable investments. The lower the EATR, the more attractive is (ceteris paribus) the country as a location for international companies. The EMTR measures the effective corporate tax burden on a marginal investment earning only its cost of capital. The lower the EMTR, the larger the theoretically optimal level of that investment. For further discussion on these tax rates and their economic effects see Devereux and Griffith (1998), Devereux (2004) and Buettner and Ruf (2005). 
Table 3. Effective Average Tax Rates (EATR) at Corporate Level

\begin{tabular}{l|c|c}
\hline \multicolumn{1}{c|}{ Slovak Republic } & $\mathbf{2 0 0 3}$ & $\mathbf{2 0 0 4}$ \\
\hline Overall Average (EATR) & $\mathbf{2 2 . 1 \%}$ & $\mathbf{1 6 . 7 \%}$ \\
Average for Each Source of Finance & & $18.9 \%$ \\
Retained Earnings & $25.0 \%$ & $18.9 \%$ \\
New Equity & $25.0 \%$ & $12.3 \%$ \\
Debt & $16.3 \%$ & $15.5 \%$ \\
Average for Each Asset & $21.3 \%$ & $15.6 \%$ \\
Buildings & $20.5 \%$ & $15.9 \%$ \\
Intangibles & $20.9 \%$ & $18.7 \%$ \\
Machinery & $24.6 \%$ & $17.7 \%$ \\
Financial assets & $23.3 \%$ & \\
Inventories & & \\
\hline
\end{tabular}

Source: Jacobs et al. $(2003,2004)$.

Table 4. Effective Marginal Tax Rates (EMTR) at Corporate Level

\begin{tabular}{c|c|c}
\hline Slovak Republic & 2003 & 2004 \\
\hline Overall Average (EMTR) & $15.2 \%$ & $10.7 \%$ \\
\hline
\end{tabular}

Source: Ernst and Young and ZEW.

Figure10 Effective average tax burden of companies in Europe ${ }^{1}$

Per cent

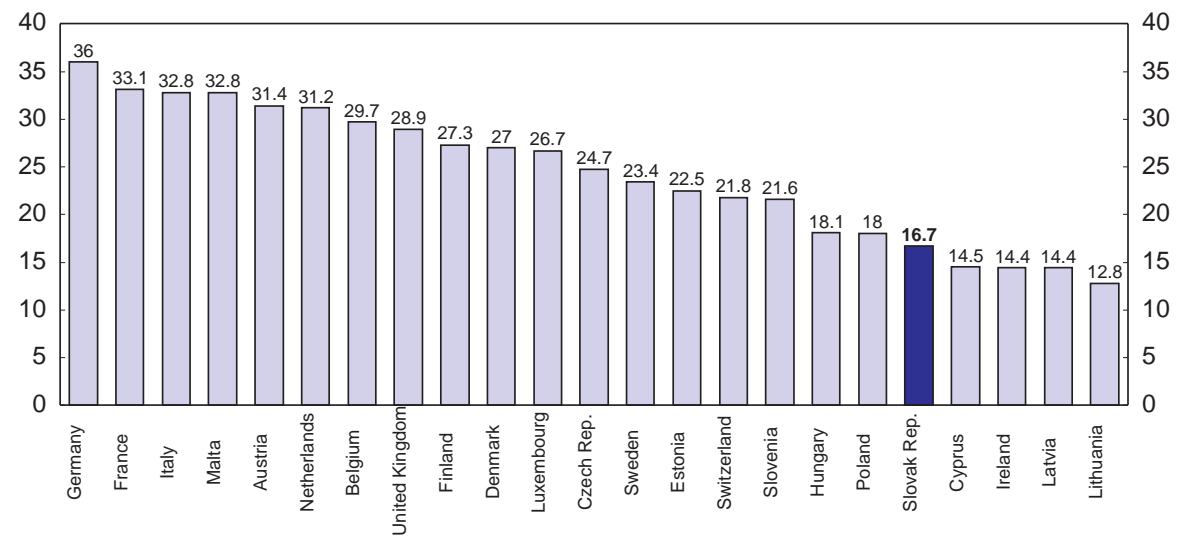

1. 2004 data for Slovak Republic, Germany, Malta, Czech Republic, Estonia, Slovenia, Hungary, Poland, Cyprus, Latvia and Lithuania; 2003 for other countries.

Source: ZEW Economic Studies Vol. 28. 
37. The changes in capital income taxation have also improved the allocation of capital as the system has become more neutral with respect to investment financing by debt versus equity. The reform eliminated double taxation of corporate income, with distributed profits being fully taxed at the corporate level, while dividend income is not taxed at the household level. As a result, the return of an investment which has been financed by new equity (and which is distributed as dividends) bears a similar marginal tax rate (19\%) as the return from a debt-financed investment (where interest payments are deducted at the corporate level while interest income is taxed at the household level). The reform thus reduced capital costs for investment financed by new equity and therefore improves financing conditions also for smaller innovative firms which may wish to rely more on new equity financing than older firms. ${ }^{26}$

\section{...but some tax distortions remain}

38. By contrast, the effective tax rate on the return of an investment which is financed by retained profits - while it was also reduced by the reform - remains higher than the effective tax rate on the return on a debt-financed or new equity-financed investment. This is because the return of a retained earningsfinanced investment is taxed both at the corporate level (by the corporate tax of 19\%) and at the household level (by the capital gains tax of 19\% on the increase in the share prices arising from these re-invested profits); since capital gains are not taxed when they accrue but only on realization, the effective capital gains tax is somewhat lower than the statutory tax rate of $19 \%$ but the tax distortion between the debt- and new equity-financed investment and the investment financed by retained profits remains (see Box 2). While in theory firms could finance the marginal investment by debt or new equity, in practice there may be limits to the extent they can do this and firms may have to fund marginal investment through retained earnings. Moreover, very small firms may have no access to equity and debt markets at all, thus facing a tax disadvantage. One solution would be to set the capital gains tax to zero, as is the case in a number of other OECD countries. Another possibility would be to exempt the capital gains which arise from re-invested profits but maintain the tax on windfall capital gains. Although such a system is more complex, it has been implemented in Norway and would make the tax system in Slovakia neutral with respect to all sources of investment financing while at the same time considering equity concerns with respect to windfall gains.

\section{Box 2. Assessing distortions of capital taxation between different sources of investment financing: some theoretical considerations}

Capital taxation affects saving and investment by driving a wedge between the pre-tax and the post-tax rates of return. Saving is reduced if the post-tax rate of return falls and substitution effects (from future to current consumption, causing current savings to fall) dominate income effects (the lower net return requires higher savings to meet a targeted level of consumption, causing current savings to rise). Investment is reduced if taxation increases the required minimum rate of return before taxes so that the less productive investments are not undertaken any longer. Capital taxation may also have different effects on the various types of investment (equipment investment, construction, inventories), the various sources of investment financing (debt, retained profits, new issues of shares), and the various owners of capital (households, indirect holdings via insurance companies, domestic versus foreign owners). Capital taxation can therefore distort the structure of capital formation and its financing and thus lead to economic inefficiencies. An analytical tool to analyse these tax distortions is to examine the effects of capital taxes on the capital cost of investment or the minimum required rate of return before taxes. These effects depend not only on the statutory corporate tax rate but also on the corporate tax base which is affected (among others) by depreciation allowances (or more precisely by the difference between tax depreciation and the true economic depreciation) and other investment

26. Before the reform, in 2003, there was a $15 \%$ final withholding tax on dividend income and a $25 \%$ corporate tax, producing an overall tax rate on dividend income of $36.3 \%$ of pre-tax distributed profits. Prior to that, in 2000, the corporate income tax was $29 \%$ and the dividend withholding tax $15 \%$, producing an overall tax rate of $39.7 \%$ - more than double the current overall tax rate of $19 \%$. 


\section{$\mathrm{ECO} / \mathrm{WKP}(2005) 35$}

incentives (investment tax credits etc.). The effects also depend on the tax treatment of dividends, capital gains and interest income at the level of savers and can therefore be different for the various sources of investment financing.

Assuming (for simplification) that depreciation allowances are equal to the true economic depreciation and that there are no investment allowances and that inflation is zero, it can easily be seen that for a debt-financed investment formula (1) applies:

(1) $p=r$

where $p$ is the required minimum rate of return before tax (which is also the capital cost of the investment net of depreciation) and $r$ is the (risk-adjusted) real market interest rate. Thus, the minimum and pre-tax rate of return of a debt-financed investment is equal to the real market interest rate and is therefore not affected by taxation. This is so because the return on debt-financed investment is not taxed at the level of the firm (as interest payments are deductible) but only at the level of the saver where interest income is taxed similar as other interest income (in Slovakia 19\%) so that savers receives the same net return as they would have invested in other interest-bearing assets of the capital market (such as government bonds).

If the firm finances its (marginal) investment by equity it has to earn a pre-tax rate of return which after all taxes paid by the firm and the savers provide savers with the same (risk-adjusted) net rate of return as if they would have invested their savings in the bond market (opportunity costs). Two cases of equity financing of an investment can be distinguished: financing by retaining profit and financing by issuing new shares. If the firm retains profits it has to pay the corporate tax. With the retention of profits the value of the firm rises which is reflected in higher share prices and so that capital gains accrue to the owners of shares. These capital gains may or may not be taxed depending on the existence of a capital gains tax. Were capital gains are taxed (as in Slovakia) the tax base is generally not current accruals but only realised capital gains and with realisation in the (perhaps distant) future the effective tax rate on accrued capital gains $z$ can be significantly lower than the statutory tax rate. But an equity-financed investment also has to earn a pre-tax rate of return which after all taxes yields a net return to savers which is equal to what they would have earned by investing in the bond market (opportunity costs). Thus, the tax rate on interest income of savers (households) also affects the minimum pre-tax rate of return of this type of equity financing. Formula (2) determines (under the simplifications made above) if capital taxation introduces a distortion between debt-financed investment and investment financed by retained profits:

(2) $t+z(1-t)>m$

$t+z(1-t)=m$

$t+z(1-t)<m$ tax distortion against retained earnings

no tax distortion

tax distortion in favour of retained earnings

where $t$ is the corporate tax rate (on retained profits), $z$ is the (effective) capital tax and $m$ is the income tax on interest income. Thus, when capital gains are not taxed $(z=0)$ and the corporate tax rate is equal to the tax rate on interest income $(t=m)$, there is no tax distortion as the return on investment financed by retained profits bears the same tax burden as an alternative investment in government bonds. In the case of Slovakia the corporate tax rate is equal to the tax rate on interest income $(\mathrm{t}=\mathrm{m}=19 \%)$, but as there also exists a capital gains tax there is a tax distortion [of $z(1-0.19)$ ] against retained profits. This tax distortion would be eliminated if the capital gains tax would be abolished. From formula (2) it can also be seen that tax neutrality between equity-financed and debt-financed investment can also be achieved without taxing corporate profits at all $(\mathrm{t}=0)$. In this case the effective tax rate on capital gains must, however, be equal to the tax rate on interest income $(z=m)$.

If the firm finances its investment by issuing new shares (new equity), one has to consider the taxation of dividends. Corporate tax systems are quite different on how they tax dividends. In so-called classical corporate tax systems distributed profits are both fully taxed at the level of the firm and at the level of dividend recipients, so that there is double taxation. By contrast, systems with full imputation of the corporate tax at the household level tax dividends (de facto) only at the level of households, so that there is no double taxation. In the Slovak system distributed profits are fully taxed at the level of the firm (at 19\%) while dividend income is not taxed at the household level so that there is no double taxation. Thus there is no tax distortion for investment financing by new equity as the tax burden is equal to that of a debt-financed investment (19\%). 


\section{The distributive effects are unequal between income groups}

39. Concerning equity or fairness it is clear that any tax reform which is revenue-neutral means that some groups will gain while others will lose. Indeed there are various elements of the Slovak tax reform which tend to change income distribution in favour of the more affluent households. First, the introduction of a single marginal tax rate on personal income which replaced the previous progressive rate structure has benefited households with higher incomes. In the international discussion about the pros and cons of a flat rate income tax this adverse effect on equity has generally been seen as the Achilles heel of such reform. However, the case of Slovakia illustrates that the relatively high basic tax exempt income threshold allows some progressivity in the average tax rate to be retained. ${ }^{27}$ Figure 2 shows that the average income tax rate still tends to increases with income, except for those on incomes higher than 3 times the APW, for whom the ceiling on social security contributions introduces a slightly regressive component. This figure also shows that average tax rates are now significantly lower for most families, who now receive (refundable) tax credits for each child as well as the full personal tax exemption for both spouses (regardless of whether the second spouse is working).

40. Second, the reduction of the effective tax on dividend income benefits higher income households who are more likely to be recipients of dividend income than poorer households. Third, the shifting of the tax burden from income onto consumption (and abolishing the reduced VAT rate for basic foodstuff) also shifts the burden away from high income earners, who tend to consume less as a share of their income. The reform increased the VAT burden as a percent of household net income for all income brackets with the biggest increases occurring for the lowest-income households; the size of the burden now ranges from around $15 \%$ of household net income in the lowest income bracket to around $13 \%$ in the highest bracket (Figure 11).

Figure 11. VAT burden and the income distribution

In per cent of household income, by decile groups of household net income

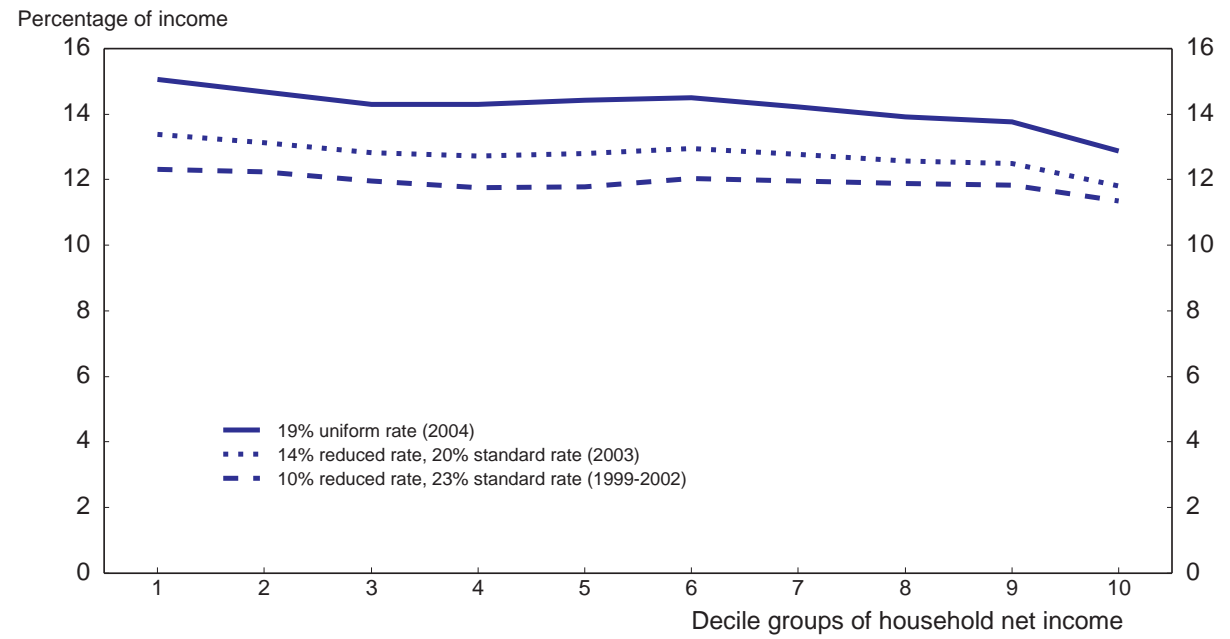

Source: Slovak Ministry of Finance, household net income data from Microcensus.

41. Based on this analysis, it seems that the overall effect of the tax reform has probably been to increase income inequality somewhat relative to the previous system, as the redistributive effect of the tax

27. Similar conclusions can be reached for the other countries that have introduced single rate income tax systems. 


\section{ECO/WKP(2005)35}

system is now smaller. While the low income earners and the very high income earners (those earning more than three times the APW) appear to have gained, particularly those with families, workers in the middle range of income, particularly single earners, appear to be worse off. To date, however, no empirical studies quantifying the overall effects on income distribution are available.

42. Welfare reform has also had a big impact on income distribution. In particular, the cuts in social assistance benefits suggest a significant increase in the number of people living in poverty, particularly among the Roma population (who make up a large proportion of the long-term unemployed). For example, a long-term unemployed couple with four children saw their total net income roughly halve from 15781 SKK per month in 2002 (around 400 euros) to 7550 SKK per month in 2004 (around 200 euros). ${ }^{28}$ For these people, the provision of public health services, education and job-creation services (among others) have become even more important, while at the same time good health and employment outcomes become more difficult to achieve. ${ }^{29}$ This places a considerably greater burden on the regional authorities who, under fiscal decentralisation, are now responsible for the provision of all social services.

43. While an assessment of the fairness of a tax system depends on value judgments, it is clear that any change in income distribution could lead to dissatisfaction of those who have to pay more or receive less, particularly if they are relatively poor. It is therefore not surprising that the Slovak population is quite sharply divided between those who strongly support these reforms and those who strongly disagree.

44. The issue of fairness in taxation cannot, however, be separated from the issue of efficiency. In so far as the previous generous welfare benefits (relative to wages) together with high marginal tax rates had created unemployment and poverty traps, it did not alleviate but rather perpetuated poverty while the new system may help people to get out of poverty. This will be particularly true if further steps are taken to promote demand for low-skilled labour, and opportunities for low-skilled people to improve their level of human capital will also play a role. Furthermore, if - as suggested above - the tax reform increases the capital stock and improves its allocation, labour productivity will increase, raising real wages so that workers, including the low-skilled, will over the longer-term also benefit from lower taxes on capital. Nonetheless, those persons who do not participate in the labour market, and especially those who do not participate in activation programmes, will remain worse-off as they have to pay the higher VAT while social benefits have been reduced.

28. These calculations are for a family with four children aged 13, 10, 7 and 4 . If one of the children is under the age of 3, eligibility for the parental allowance means that total net income is slightly higher (8 448 SKK per month in 2004) but still more than 50\% lower than in 2002 (18 564 SKK per month). These calculations include all housing and other benefits. Due to these cuts, net replacement rates for these families have fallen from around $112 \%$ of the APW in 2002 to around 40 to $45 \%$ in 2004 (depending on the children's age).

29. Unemployed people living in poverty have fewer resources to improve their employability prospects. There are also well-established links between poverty and health and education outcomes. 


\section{BIBLIOGRAPHY}

Buettner, T. and M. Ruf (2005), "Tax incentives and the location of FDI: evidence from a panel of German multinationals", Deutsche Bundesbank Discussion Paper Series 1: Economic studies No 17/2005.

Carey, D. (2003), “Tax reform in Belgium”, OECD Economics Department Working Papers No. 354.

Daveri, F. and G. Tabellini (2000), "Unemployment, growth and taxation in industrial countries", Economic Policy: A European Forum, Vol. 30, April, pp. 47-101.

De Haan, J., J.-E. Sturm and B. Volkerink (2003), "How to measure the tax burden on labour at the macrolevel", CESIFO Working Paper No. 963.

Devereux, M.P. and R. Griffith (1998), "Taxes and the location of production - evidence from a panel of US multinationals", Journal of Public Economics 68, 335-367.

Devereux, M.P. (2004), "Measuring Taxes on Income from Capital", in: Measuring the Tax Burden on Capital and Labor, edited by Peter B. Sørensen, CESifo Seminar Series, The MIT Press Cambridge, Massachusetts.

Jacobs, O.H., H. Spengel, M. Finkenzeller and M. Roche (2003, 2004): "Company Taxation in the New EU Member States", First and Second Edition, Ernst and Young and ZEW, Mannheim/Frankfurt.

Leibfritz, W., J.Thornton and A. Bibbee (1997), "Taxation and economic performance", OECD Economics Department Working Papers No. 176.

Moore, D. (2005), “Slovakia's 2004 Tax and Welfare Reforms”, IMF Working Paper WP/05/133.

Nickell, P. (2003), “Employment and Taxes”, CESIFO Working Paper No. 1109.

OECD (2005a), “OECD Economic Survey of the Slovak Republic”, Paris.

OECD (2005b), “OECD Economic Survey of France”, Paris.

OECD (2004), “OECD Employment Outlook 2004”, Paris.

OECD (2003), “OECD Employment Outlook 2003”, Paris.

WEF (2004), “The Global Competitiveness Report, 2004-2005”, edited by M. Porter, K. Schwab, X. Salai-Martin, A. Lopez-Claros. World Economic Forum, Geneva, Switzerland.

World Bank (2005), "World Bank EU-8 Quarterly Economic Report April 2005 Part II: Special topic: Labour taxes and employment in the EU8". The World Bank, Washington DC, USA. 


\section{WORKING PAPERS}

The full series of Economics Department Working Papers can be consulted at www.oecd.org/eco/Working_Papers/

447. The Education Challenge in Mexico: Delivering Good Quality Education to All (October 2005) Stéphanie Guichard

446. In Search of Efficiency: Improving Health Care in Hungary (October 2005) Alessandro Goglio

445. Hungarian Innovation Policy: What's the Best Way Forward? (October 2005) Philip Hemmings

444. The Challenges of EMU Accession Faced by Catch-Up Countries: A Slovak Republic Case Study (September 2005) Anne-Marie Brook

443. Getting better value for money from Sweden's healthcare system (September 2005) David Rae

442. How to reduce sickness absences in Sweden: lessons from international experience (September 2005) David Rae

441. The Labour Market Impact of Rapid Ageing of Government Employees: Some Illustrative Scenarios (September 2005) Jens Høj and Sylvie Toly

440. The New OECD International Trade Model (August 2005) Nigel Pain, Annabelle Mourougane, Franck Sédillot and Laurence Le Fouler

439. The French Tax system: Main characteristics, recent developments and some considerations for reform (July 2005) Willi Leibfritz and Paul O’Brien

438. The Effects of EMU on Structural Reforms in Labour and Product Markets (July 2005) Romain Duval and Jørgen Elmeskov

437. Product Market Competition andEconomic Performance in New Zealand (July 2005) Annabelle Mourougane and Michael Wise

436. Getting the Most out of Public Sector Decentralisation in Spain (July 2005) Isabelle Joumard and Claude Giorno

435. Sources of Inflation Persistence in the Euro Area (July 2005) Boris Cournède, Alexandra Janovskaia, Paul van den Noord

434. Measuring Cyclically-Adjusted Budget Balances for OECD Countries (July 2005) Nathalie Girouard and Christophe André

433. Product Market Competition and Economic Performance in the United Kingdom (June 2005) Maria Maher and Michael Wise

432. The Benefits of Liberalising Product Markets and Reducing Barriers to International Trade and Investment: the Case of the United States and the European Union (June 2005)

431. Boosting Growth through Greater Competition in Denmark (May 2005) Martin Jørgensen 
430. Fifteen Years of Economic Reform in Russia: What Has Been Achieved: What Remains to be Done? (May 2005) Rudiger Ahrend and William Tompson

429. Assessing the OECD Job Strategy: Past Developments and Reforms (May 2005) Nicola Brandt, Jean-Marc Burniaux and Romain Duval

428. Ageing, Welfare Services and Municipalities in Finland (May 2005) Jens Lundsgaard

427. The Impact of Structural Policies on Trade-Related Adjustment and the Shift to Services (April 2005) Per Mathis Kongsrud and Isabelle Wanner

426. Product Market Competition and Economic Performance in Iceland (April 2005) Thomas Laubach and Michael Wise

425. Enhancing Brazil's Regulatory Framework for Network Industries: The Case of Electricity, Oil and Gas, and Water and Sanitation (April 2005) Edmar Almeida and Nanno Mulder

424. Education Attainment in Brazil: The Experience of FUNDEF (April 2005) Luiz de Mello and Mombert Hoppe

423. Estimating a Fiscal Reaction Function: The Case of Debt Sustainability in Brazil (April 2005) Luiz de Mello

422. Product Market Competition and Economic Performance in the Netherlands (April 2005) Maria Maher and Michael Wise

421. Product Market Competition and Economic Performance in Canada (April 2005) Maria Maher and Jay Shaffer

420. The Impact of Ageing on Demand, Factor Markets and Growth (April 2005) Joaquim Oliveira Martins, Frédéric Gonand, Pablo Antolin, Christine de la Maisonneuve and Kwang-Yeol Yoo.

419. Product Market Regulation in OECD Countries: 1998 to 2003 (February 2005) Paul Conway, Véronique Janod and Giuseppe Nicoletti

418. Reforming Turkey's Public Expenditure Management (February 2005) Rauf Gönenç, Willi Leibfritz and Erdal Yilmaz

417. Fiscal Gimmickry in Europe: One-Off Measures and Creative Accounting (February 2005) Vincent Koen and Paul van den Noord

416. Getting the Most out of Public Sector Decentralisation in Japan (January 2005) Isabelle Joumard and Tadashi Yokoyama

415. Structural Policy Reforms and External Imbalances (January 2005) Mike Kennedy and Torsten Sløk

414. The Jobs Challenge in Poland: Policies to Raise Employment (January 2005) Andrew Burns and Przemyslaw Kowalski

413. Product Market Competition and Economic Performance in Finland (December 2004) Jens Høj and Michael Wise 